\title{
Noninvasive Assessment of Reperfusion and Reocclusion After Thrombolysis in Acute Myocardial Infarction
}

\author{
Peter Klootwijk, MD, Christa Cobbaert, PharmD, Paolo Fioretti, MD, Peter Paul Kint, RN, \\ and Maarten L. Simoons, MD
}

\begin{abstract}
The clinical significance of ST-segment changes and of the time course of appearance in serum of different cardlac protelns has been reviowed for the dlagnosis of coronary reperfusion and reocclusion after thrombohysis. In particular, the value of serlal 12-lead electrocardlographic (ECG) studles, of Holter monitoring, and of continuous multllead computer-assisted ECG monltoring is compared. Regarding the serum protelns, the clinical significance of reperfusion Indlces described so far for serum creatine klnase (CK), its iscenzyme serum creatine kinase MB, the CK lsoforms, and myoglobin is revlewed. Emphasis is placed on (1) the calculation method used for dertving the reperfuston indlces; (2) the sensittitity and the specificity of the reperfusion Indces; (3) the minimum tum-around time needed to produce the reperfusion indlces (depending on the practicability of the analytical and calculation methods and their applleability in an emergency laboratory); (4) the ablity of the indices to produce rellable estimates of reperfusion efficacy of the thrombohytic agents under study; and (5) the ability of the marker proteins to detect reinfarction as well as the sultability of the markers to detect real-time necrosis.
\end{abstract}

(Am J Cardlol 1993;72:75G-84G)

From the Thoraxcenter and Department of Clinical Chemistry, Erasmus University and University Hospital Dijkzigt, Rotterdam, The Netherlands.

Address for reprints: Paolo Fioretti, MD, Thoraxcenter, Ba 300, Academisch Ziekenhuis Rotterdam, Dr. Molewaterplein 40, 3015 GD Rotterdam, The Netherlands.

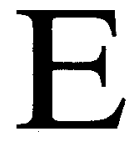

arly reperfusion and sustained patency of the infarct-related coronary artery are important determinants of survival. ${ }^{1}$ Thus, more aggressive therapy may be indicated if thrombolytic therapy fails to open the occluded vessel or if reocclusion of an initially reperfused coronary artery occurs. In contrast, administration of thrombolytic agents may be discontinued to minimize bleeding risk in patients with a rapidly reperfused artery. In this manner, therapy of acute myocardial infarction can be tailored to the status of the infarct-related vessel. In order to guide therapy, continuous monitoring of the vessel status is mandatory. Coronary angiography is the "gold standard" to assess patency and occlusion or reocclusion. However, angiography supplies only very momentary information on the status of the infarctrelated vessel, and this invasive technique is not useful for continuous monitoring.

Noninvasive methods for monitoring reperfusion of the infarct-related vessel include clinical markers (such as resolution of chest pain), electrocardiographic (ECG) findings (such as the occurrence of accelerated idioventricular rhythm and normalization of the ST segment), and monitoring of specific cardiac proteins in plasma. ${ }^{2-5}$ Resolution of chest pain is very subjective and may frequently be related to analgesic medication. Certain arrhythmias suggesting reperfusion are specific, but not sufficiently sensitive, actually to detect reperfusion. Thus, neither of these 2 methods can be used to predict reliably coronary vessel status. In this overview, use of continuous multilead ECG monitoring and of monitoring of myocardial proteins in serum is discussed.

\section{ROLE OF THE ELECTROCARDIOCRAM FOR DETECTION OF REPERFUSION AND PATENCY}

Following reperfusion, as documented by coronary angiography, resolution of ST-segment elevation occurs earlier, with an almost 5-fold faster time course than the changes associated with the 


\begin{tabular}{|c|c|c|c|c|c|c|c|c|c|}
\hline Study & Criteria & $\begin{array}{l}\text { No. ECGs/ } \\
\text { Assessment } \\
\text { Interval }\end{array}$ & $\begin{array}{l}\text { Interval } \\
\text { Thrombolysis } \\
\text { Angiography }\end{array}$ & $\begin{array}{l}\text { No. } \\
\text { Pt. }\end{array}$ & $\begin{array}{c}\text { Pt. with } \\
\text { Criteria } \\
(\%)\end{array}$ & $\begin{array}{l}\text { Sensi- } \\
\text { tivity } \\
(\%)\end{array}$ & $\begin{array}{l}\text { Speci- } \\
\text { ficity } \\
(\%)\end{array}$ & $\begin{array}{l}\text { Positive/ } \\
\text { Negative } \\
\text { Predictive } \\
\text { Value }(\%)\end{array}$ & $\begin{array}{l}\text { Comment } \\
\text { on Study }\end{array}$ \\
\hline Kircher et al ${ }^{3}$ & $\begin{array}{l}? \downarrow \text { average ST elevation, } \\
2 \text { worst leads }\end{array}$ & $2 \mathrm{ECGs} / 90 \mathrm{~min}$ & $90 \mathrm{~min}$ & 56 & 34 & 52 & 88 & $88 / 46$ & $\begin{array}{l}\text { Correct study design but } \\
\text { criteria not defined }\end{array}$ \\
\hline $\begin{array}{l}\text { Clemmensen } \\
\text { et al }{ }^{11}\end{array}$ & $\geq 20 \% \downarrow \Sigma$ ST elevations & $2 \mathrm{ECGs} / 180 \mathrm{~min}$ & $180 \min$ & 53 & 62 & 88 & 80 & $88 / 80$ & $\begin{array}{l}\text { Correct study design, best } \\
\text { serial ECG study }\end{array}$ \\
\hline Saran et al $1^{12}$ & $\begin{array}{l}>25 \% \downarrow \text { ST elevation, } \\
\text { worst lead }\end{array}$ & 2 ECGs/180 min & $60-90 \mathrm{~min}$ & 45 & 84 & 97 & 43 & $79 / 86$ & $\begin{array}{l}\text { Angiography before final } \\
\text { ECG assessment }\end{array}$ \\
\hline Hogg et al ${ }^{13}$ & $\begin{array}{l}\geq 50 \% \downarrow \text { ST elevation, } \\
\text { worst lead }\end{array}$ & $2 \mathrm{ECGs} / 300 \mathrm{~min}$ & $45-90 \mathrm{~min}$ & 17 & 82 & 93 & 67 & $93 / 67$ & $\begin{array}{l}\text { Angiography before final } \\
\text { ECG assessment }\end{array}$ \\
\hline Nicolau et al ${ }^{14}$ & $\begin{array}{l}\geq 50 \% \downarrow \text { ST elevation, } \\
\text { worst lead } \\
\text { within } 4 \mathrm{hr} \text { after throm- } \\
\text { bolysis }\end{array}$ & $8 \mathrm{ECGs} / 48 \mathrm{hr}$ & $<72 \mathrm{hr}$ & 101 & 49 & 58 & 83 & $92 / 37$ & $\begin{array}{l}\text { Not suitable for early } \\
\text { patency assessment }\end{array}$ \\
\hline Barbash et al15 & $\geq 50 \% \downarrow \Sigma$ ST elevations & 2 ECGs/60 min & $72 \mathrm{hr}$ & 286 & 66 & 87 & 76 & $87 / 76$ & $\begin{array}{l}\text { Not suitable for early } \\
\text { patency assessment }\end{array}$ \\
\hline $\begin{array}{l}\text { Richardson } \\
\text { et al }{ }^{16}\end{array}$ & $\begin{array}{l}\geq 2 \mathrm{~mm} \downarrow \text { ST elevation, } \\
\text { worst lead } \\
\text { or resolution within } 30 \\
\text { min }\end{array}$ & $9 \mathrm{ECGs} / 180 \mathrm{~min}$ & 6 days & 188 & 56 & 67 & 80 & $92 / 40$ & $\begin{array}{l}\text { Not suitable for early } \\
\text { patency assessment }\end{array}$ \\
\hline
\end{tabular}

natural evolution of an acute myocardial infarction. ${ }^{6-10}$ Thus, rapid resolution of ST-segment elevation is a marker of reperfusion. However, more recent studies, using serial 12-lead ECG, have questioned the reliability of ST-segment changes to predict reperfusion. ${ }^{2,3}$ Only recently, when newer techniques, such as continuous multilead ECG monitoring, became available could distinct patterns of ST-segment behavior be recognized as predicting reperfusion and patency after thrombolytic therapy.

Sorial 12-lead ECG recordings: Studies that evaluated the usefulness of ST-segment recovery from serial 12-lead ECGs as a marker of reperfusion are presented in Table I.,11-16 For proper comparison, angiographic assessment should be performed immediately after, and not before, the final serial ECG assessment. Further, assessment of patency is most important during the first few hours following thrombolytic therapy. Unfortunately, 3 studies appear invalid because of late angiography, ${ }^{14-16}$ and in 2 , angiography was planned before final ECG assessment. ${ }^{12,13}$ Finally, another study $^{3}$ did not clearly define the criteria for ST recovery. Thus, the study by Clemmensen et al ${ }^{11}$ appears to be the most valid. This study comprised 53 patients with an acute myocardial infarction treated with thrombolytic therapy. Two serial ECGs were recorded, one on admittance and the other approximately 180 minutes after the initiation of thrombolytic therapy. Directly following the second ECG, angiographic patency was assessed, using the classification of the Thrombolysis in Myocardial Infarction (TIMI) trial at first injection of contrast material. ${ }^{17}$ Reduction of the summed ST-segment elevation by $\geq 20 \%$ within 180 minutes rendered sensitivity and specificity values of $88 \%$ and $80 \%$ for ECG versus angiographic patency assessment, respectively.

On average, looking at the results of the studies on early patency assessment using serial 12-lead ECGs, it appears that a rapid reduction of STsegment elevation or depression by $\geq 20-50 \%$ of the highest previous ST value, occurring within 3 hours from start of thrombolytic therapy, is a reasonably accurate predictor of reperfusion, whereas lack of rapid ST-segment recovery suggests occlusion. Depending on the severity of ST elevation on the initial ECG, the use of either the single lead with maximal ST deviation ("worst lead") or the summed lead ST changes may be of importance. If a large ST deviation is present on the initial ECG, the ST reduction read at the single worst lead is preferable, although the reduction of the summed ST deviation may be more useful in cases of mild ST deviation.

The conflicting results of these studies reflect the limitations of serial 12-lead ECG recording for prediction of reperfusion and patency. Coronary reperfusion is a dynamic, rapidly changing process that is often accompanied by intermittent or sustained reocclusion and cyclic flow changes. ${ }^{18,19}$ One third of episodes of recurrent ST elevation are silent and may remain unrecognized unless continu- 
ous ECG monitoring is performed (Figure 1). These changes may remain unrecognized if serial ECG recording is used for monitoring. The time interval of the serial ECGs may be crucial for accurate detection of reperfusion and for interpretation of the coronary status. For example, if an undetected delayed ST (re)elevation peak precedes the moment of ST-segment elevation recovery, serial ECG recording may suggest an occluded artery if the serial measurement is taken just before the rapid decline. On the other hand, if a serial ECG is taken at the moment of a reelevation episode that followed the first period of ST recovery, initial patency following thrombolysis will be missed (Figure 2). Because treatment strategies should nowadays be based on the presence or absence of initial reperfusion, this time resolution problem may lead to erroneous decision making. Therefore, it is more convenient to use continuous ECG monitoring techniques to avoid less accurate assessments of reperfusion and patency.

Continuous ECG monitoring techniques: Several continuous ECG monitoring techniques have been evaluated for the assessment of reperfusion and patency. Holter ST-segment rccording is the easiest technique to monitor the ST segment continuously. However, it has some major limitations. Firstly, only a restricted number of leads can be monitored, which may not always reflect the area with maximal ST deviation. Further, Holter ST monitoring allows retrospective analysis only. This makes immediate feedback impossible and thus the technique cannot be used for on-line STsegment monitoring and tailoring of thrombolytic therapy. This may explain why only a few studies have evaluated this technique for early patency assessment. The only 2 representative studies are those from Hohnloser et $\mathrm{al}^{4}$ and Krucoff et $\mathrm{al}^{20}$ mentioned in Table II. Both studies demonstrate that Holter ST-segment recording may be used for ischemia monitoring. However, apart from the possibility to study reperfusion and (re)occlusion patterns retrospectively, the technique offers no major advantages above serial ECG monitoring.

More recently, computer-assisted continuous multilead ECG monitoring techniques have become available for real-time noninvasive patency assessment. These techniques use continuous ECG sampling and averaging techniques, offering a continuous real-time accurate measurement of the QRS complex and ST segments.

Two different approaches for computer-assisted ECG analysis have been developed: continuously updated multilead ST monitoring, based on on-line

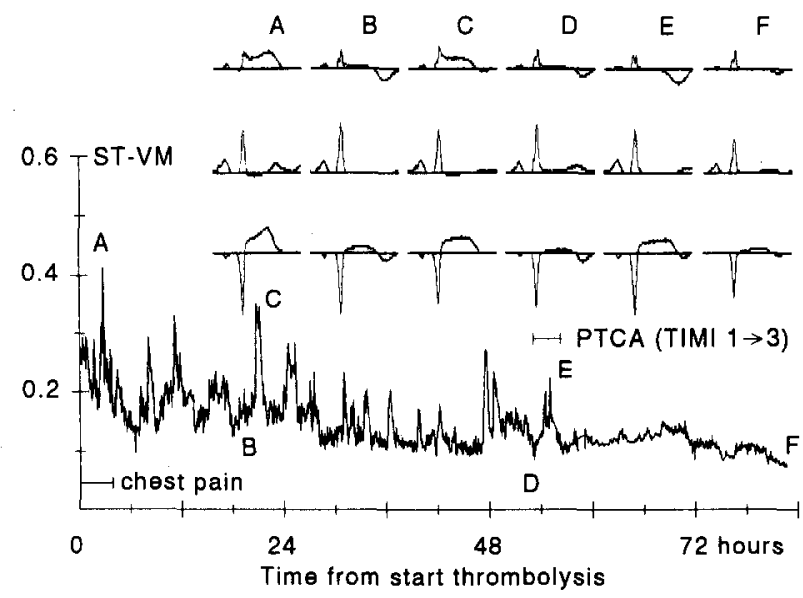

FICURE 1 Continuous electrocardlogtraphls (ECQ) recondIng (vector ECG leads $X, Y, 2$ ) of 84 hours' duration In a patient with an anterlor wall infarction. On admittance to the hospital, the patient was having chest pain, and severe ST-segtment elevation was present in leads $X$ and $Z$ (A). Over the first 48 hours, frequent eplsodes of recurrent ST elevation and recovery were present whithout chest pain (B, C, D). Because of these recurrent slient ischomk eplsodes, anglography was performed 54 hours after admittance to the hospltal. The anterlor descending artery only showed minimal fiow (Thrombohysts in Myocardlal Infarction [IMI] grade 1). After percutaneous translumlnal coronary and loplasty (G), coronary flow was restored (IMI grade 3) and lschemic eplsodes remalned absent. VM = vector magnitude.

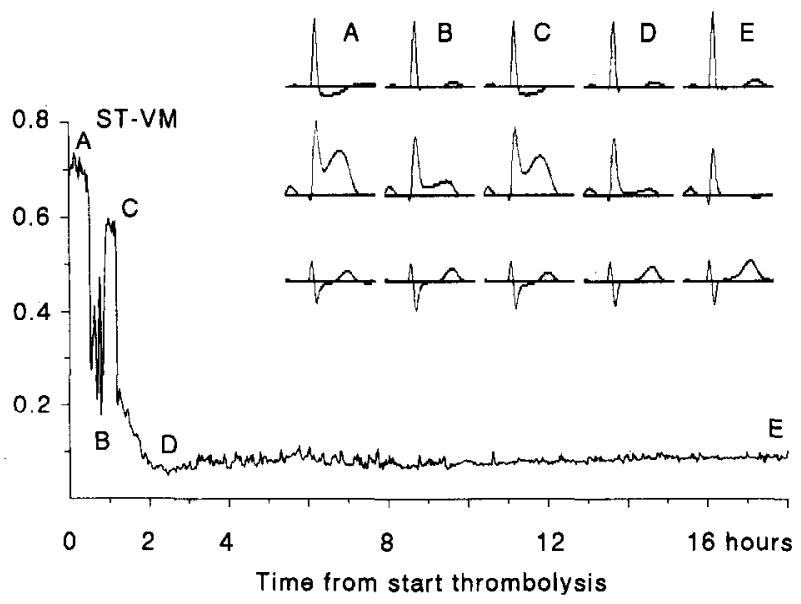

FICURE 2. Continuous electrocardlographic (ECC) recordInd (vetor ECG leads $X, Y, Z$, $n$ a patient with an inferior wal Infarction. Leads X, Y, Z more or leses resembie V5, II, and V2. On adimittance, considerable ST elevation is present in lead Y (A). The ST vector maghitude (ST-VM, sum of the ST devlation in $X, Y, Z$ ) decreases as a result of thrombolytic therapy (B), followed by recurrent ST elevation (C). Thereafter, the ST level stab"'izes (D-E). Most probabhy, reperfusion (B) and reocclusion (C) occirred, followed by permanent reperfuslon of the Infarcted area (D-G).

analysis of the conventional 12-lead ECG, using either the single lead or the summed ST level (ELI, Mortara Instrument, Milwaukee, WI $)^{21}$ and continuous vectorcardiographic monitoring. The latter technique offers the possibility of both studying on-line vectorcardiographic QRS-complex and ST- 


\begin{tabular}{|c|c|c|c|c|c|c|c|c|c|}
\hline Study & Technique & Criteria & $\begin{array}{c}\text { Interval } \\
\text { Thrombolysis } \\
\text { to Angiography }\end{array}$ & $\begin{array}{l}\text { No } \\
\text { Pt. }\end{array}$ & $\begin{array}{l}\text { Pt. with } \\
\text { Criteria } \\
(\%)\end{array}$ & $\begin{array}{l}\text { Sensi- } \\
\text { tivity } \\
(\%)\end{array}$ & $\begin{array}{l}\text { Speci- } \\
\text { ficity } \\
(\%)\end{array}$ & $\begin{array}{l}\text { Positive/ } \\
\text { Negative } \\
\text { Predictive } \\
\text { Value (\%) }\end{array}$ & $\begin{array}{l}\text { Comment } \\
\text { on Study }\end{array}$ \\
\hline Hohnloser et al ${ }^{4}$ & Holter & $\begin{array}{l}\geq 50 \% \downarrow \text { ST elevation } 1 \text { of } \\
2 \text { leads within } 90 \text { min } \\
\text { after thrombolysis }\end{array}$ & $60-90 \mathrm{~min}$ & 82 & 48 & 60 & 95 & $97 / 42$ & $\begin{array}{l}\text { Only } 2 \text { leads, short assess- } \\
\text { ment interval }\end{array}$ \\
\hline Krucoff et al ${ }^{20}$ & Holter & $\begin{array}{l}\text { Achievement of ST steady } \\
\text { state within } 100 \text { min af- } \\
\text { ter thrombolysis }\end{array}$ & $100 \mathrm{~min}$ & $36^{\star}$ & 56 & 89 & 82 & $85 / 87$ & $\begin{array}{l}\text { Less confined criteria, } \\
\text { selected group of patients }\end{array}$ \\
\hline Krucoff et a| ${ }^{19}$ & Continuous 12 lead & $\begin{array}{l}<50 \% \downarrow \text { or reelevation } \\
\text { single lead or sum of ST } \\
\text { at contrast medium injec- } \\
\text { tion }\end{array}$ & $<6 \mathrm{hr}$ & 22 & $?$ & $90 \dagger$ & $92 \dagger$ & $?$ & $\begin{array}{l}\text { Large, not defined assess- } \\
\text { ment interval, small study }\end{array}$ \\
\hline \multirow[t]{2}{*}{ Dellborg et al 22} & Vectorcardiography & $\begin{array}{l}\text { QRSVD and STVM qualita- } \\
\text { tive evaluation }\end{array}$ & At least $15 \mathrm{~min}$ & 21 & 76 & 94 & 80 & $94 / 80$ & $\begin{array}{l}\text { Pilot study, assessment } \\
\text { interval not defined }\end{array}$ \\
\hline & & $\begin{array}{l}\text { QRSVD increase } \geq 0.1 \mu \mathrm{V} / \\
\text { min, plateau }<2 \mathrm{hr}\end{array}$ & & 21 & 86 & 94 & 40 & $83 / 67$ & \\
\hline Dellborg et al ${ }^{24}$ & Vectorcardiography & $\begin{array}{l}\text { QRSVD increase } \geq 0.1 \mu \mathrm{V} / \\
\min , \text { plateau }<2 \mathrm{hr} \\
\text { STVM decrease } \geq 0.83 \\
\mu V / \text { min qualitative evalu- } \\
\text { ation }\end{array}$ & $90 \mathrm{~min}$ & 96 & 65 & 83 & 73 & $89 / 61$ & $\begin{array}{l}\text { Correct study design, short } \\
\text { assessment interval }\end{array}$ \\
\hline
\end{tabular}

segment changes simultaneously (Mida1000 and Coronet, Ortivus Medical, Täby, Sweden).$^{22}$

Using these continuous digital monitoring techniques, 5 distinct patterns of ST-segment behavior following thrombolysis have been observed ${ }^{19,22}:$ (1) rapid ST recovery without reelevation; (2) rapid ST recovery following a delayed ST-elevation peak; (3) persistent ST elevation without a recovery pattern; (4) rapid ST recovery followed by recurrent ST elevation; and (5) a delayed ST-elevation peak followed by a rapid ST recovery and recurrent ST elevation. The first 3 patterns may point directly to the status of the infarct-related vessel. Rapid ST recovery without reelevation or a rapid ST recovery following a delayed ST-elevation peak both appear to be highly suggestive of reperfusion of the infarctrelated artery, whereas persistent ST elevation without a recovery pattern suggests persistent occlusion, provided that significant ST elevation is present at the start of the monitoring period. Rapid ST recovery followed by recurrent ST elevation or a delayed ST-elevation peak followed by a rapid ST recovery and recurrent ST elevation may be less specific and may suggest unstable reperfusion. Patency assessment may then be difficult.

In Table II the 3 studies using continuous multilead and vectorcardiographic monitoring are listed. Krucoff et al $^{19}$ recently reported on either the presence of 1 episode of $\geq 50 \%$ ST recovery (worst single lead or the summed ST deviation of all 12 leads), its absence, or recurrent ST elevation, using continuous updated 12-lead computer-assisted ST monitoring. Absence of ST recovery or reelevation at the moment of angiographic assessment predicted occlusion of the infarct-related vessel with sensitivity of $90 \%$ and specificity of $92 \%$. However, the time interval between hookup and final ECG and angiographic assessment was rather long, up to 6 hours, making assessment easier and only 22 patients were studied. Dellborg et al $^{22-24}$ reported on vectorcardiographic assessment of reperfusion and patency. All of their studies used both QRSvector difference and ST-vector magnitude changes for prediction of patency. In a pilot study of 21 patients, sensitivity and specificity for patency at angiography were $94 \%$ and $80 \%$, respectively, if a rapid change of both the QRS-vector difference and the ST-vector magnitude was observed, ending in a stcady statc. If only the QRS-vector difference changes were used, sensitivity remained $94 \%$, but specificity dropped to $40 \% .{ }^{23}$

In a recent study, preliminarily reported in an abstract form and recently submitted for publication, Dellborg et $\mathrm{al}^{24}$ studied 96 patients using computer-assisted vectorcardiographic monitoring. More refined criteria were used and the angiographic assessment interval was fixed at 90 minutes as much as possible. Sensitivity and specificity for identification of patency were $81 \%$ and $70 \%$, respectively.

How should the ECG be used to detect reperfusion in cllinical practice? On the basis of the 
overall findings in the literature, it is suggested that a baseline ECG should be recorded or the patient should be hooked up to a continuous ECG monitoring system immediately on admittance to the hospital. Obviously, hookup should not delay the start of therapy but should preferably be done before thrombolytic therapy has been initiated. The lead with maximal ST deviation should be used for ST monitoring. If less pronounced ST deviation is present, the sum of the ST deviations should be monitored. If only serial ECG recordings are used, short time intervals, $<10$ minutes, should be chosen for ECG recordings until ST recovery has occurred and has stabilized (Figures 1 and 2). If no ST recovery is observed within 3 hours after the start of thrombolytic therapy, this will be highly suggestive of persistent occlusion. If continuous on-line ECG recording techniques are used, the detection of ST-segment recovery will be easier and also reelevation episodes may be observed more accurately, offering the possibility of applying early change of treatment strategy, if necessary.

From the few studies on carly patency assessment using ECG monitoring techniques, it may be deduced that rapid $\geq 50 \%$ ST recovery may prove to be the most valid criterion. However, ST-vector magnitude and QRS-vector difference changes may comprise complementary information on the coronary vessel status that are not yet studied in detail. The upcoming results of the Global Utilization of Streptokinase and t-PA for Occluded Arteries (GUSTO) trial, in which an ST monitoring substudy using both Holter, multilead, and vectorcardiographic ECG monitoring is included, will provide more information on which criteria and time intervals should be applied in order to predict more accurately reperfusion, patency, and (re)occlusion.

\section{ROLE OF CARDIAC SERUM PROTEINS}

It is generally accepted ${ }^{25-27}$ that, in casc of successful reperfusion, cardiac enzymes appear earlier in the peripheral circulation, compared with unsuccessful reperfusion. Most studies on serum markers of reperfusion have been performed using serial measurements of creatine kinase (CK), its isoenzyme CK-MB, and myoglobin (Figures 3-5).

Creatine kinase and creatine kinase MB: Cytoplasmic CK is a dimer $\left(\mathrm{M}_{\mathrm{r}} 86,000-89,000\right)$ consisting of 2 subunits: an $M$ subunit $\left(M_{r} 43,000\right)$ and a $B$ subunit $\left(M_{r} 44,500\right)$, each encoded by a separate gene. ${ }^{28}$ The subunits combine to give 3 isoenzymes: CK-MM, CK-MB, and CK-BB. ${ }^{29}$ In

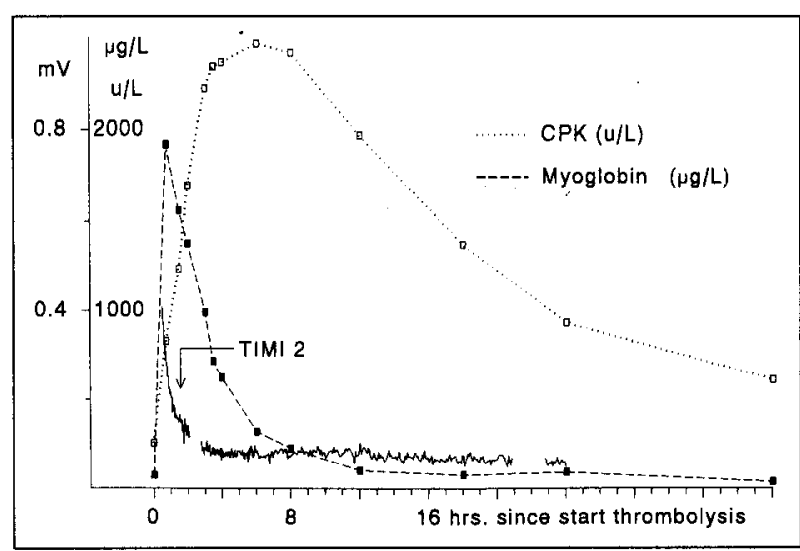

FGURE 3. Combined monitoring of ST-segment changes (conthuous lno) and serlal ascesement of myoghohin and creatine kinase (CPK), In case of succesoful recanalization. The drop of ST segment elovation ls rapld, and the slope serum rise of myoglobin ls more rapld than that of creatine kinase.

patients with an acute myocardial infarction, blood $\mathrm{CK}$ and CK-MB levels become abnormal 6-8 hours after infarction, peak in 12-24 hours, and become normal approximately 48 hours after infarction. ${ }^{30}$

CK and/or CK-MB determinations are usually available on a stat basis in emergency laboratories. Most laboratories make use of an enzymatic method for total CK. The CK assay is a European Standardized Method that can easily be adapted on automated clinical chemistry analyzers. Results are available in $15-20$ minutes. CK-MB activity is frequently measured after polyclonal immunoinhibition of the $\mathrm{M}$ subunit. This method is also easily applicable on routine clinical chemistry analyzers and results are produced in 15-20 minutes. False high CK-MB activities are produced in case of hemolysis because of adenylate kinase interference and in case of presence of macro-CK. Consequently, immunologic CK-MB mass assays (e.g.,

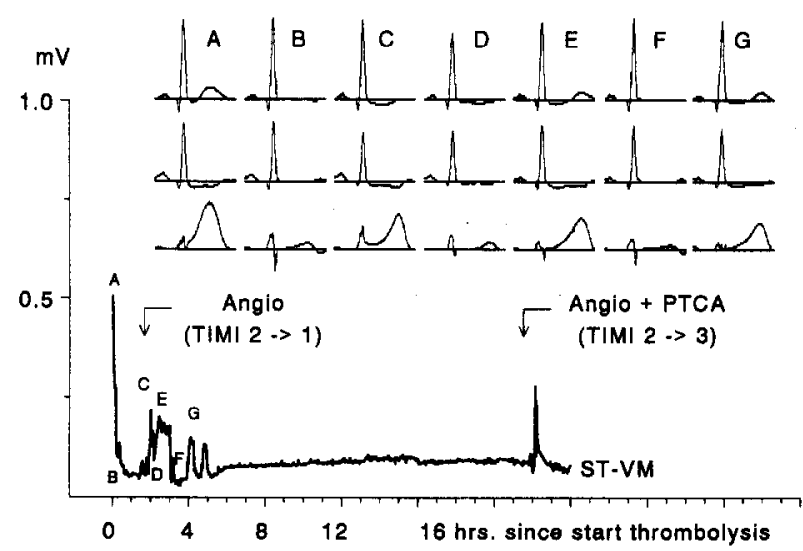

FCURE 4. Monitering of ST vector madnitude (MM) changes in a case of a pationt with several recurrent reocclusions, with andjographic (Ando) documentation. PTCA = percitaneous transhuminel coronary andioplasty; $\mathrm{TWMI}=$ Thrombohysis in Myocardial lnfarction. 
CK-MB on IMx, Abbott; CK-MB on Stratus, Baxter) gain interest nowadays because these methods are specific and do not suffer from macro-CK nor from adenylate kinase interference. Results can be produced in 20-45 minutes, depending on the type of immunoassay.

Lewis et al $^{31}$ described a rapid initial absolute increase in plasma CK and CK-MB activities (units per liter per hour) following reperfusion. The authors calculated a mean relative first-hour increase of plasma $\mathrm{CK}$ activity of $34 \pm 18 \%$ (mean \pm SD) of the peak increase (range, 13$67 \%$ ) and a relative first-hour increase in CK-MB activity of $27 \pm 13 \%$ of the peak increase (range, $13-57 \%$ ) in patients that evolved from total occlusion to TIMI flow grade 3 of the infarct-related artery. When reperfusion was incomplete or not achieved, the relative increase for CK and CK-MB was $<6 \%$ of the peak rise in the last hour of the 2.5 -hour sampling period. The authors claim that 0.5 hourly determinations of $\mathrm{CK}$ and $\mathrm{CK}-\mathrm{MB}$ during 2.5 hours following start of thrombolysis provide a useful tool for recognition of reperfusion. Shortcomings of these indices are that (1) absolute rates of increase of CK and CK-MB activities are dependent on the assay temperatures used, and (2) measuring the relative rates of increase requires knowledge of the peak increase, which becomes available only several hours later. Also, (3) the rapid and augmented release of $\mathrm{CK}$ with reperfusion has been associated with large, hemorrhagic infarcts in some dog models. ${ }^{32}$

Gore et al $^{33}$ described early peak $\mathrm{CK}$ as a reperfusion index in patients with acute myocardial infarction. In the nonreperfused group (TIMI flow

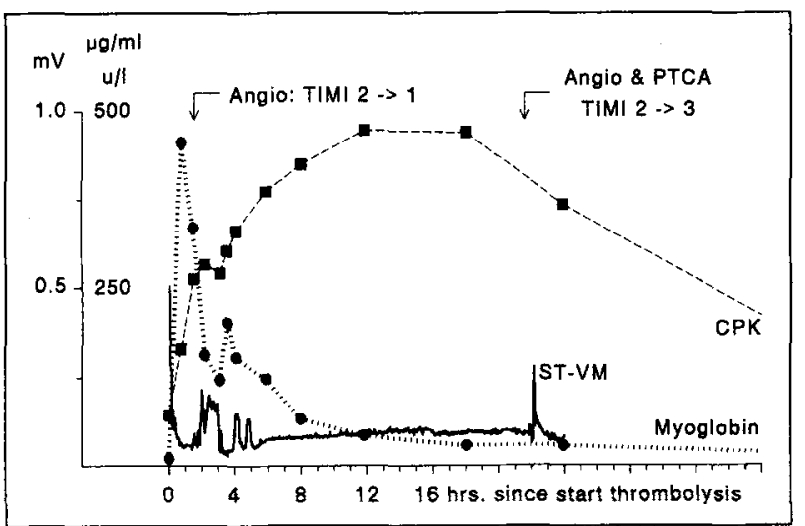

FICURE 5. Serlal aseesement of serum creatine kinase (CPK) and myoglobin in the same cace reported in Figure 2. The earhy rise of myogiobin is more rapld than that of creatine kinase. A second small rbe of myoglobln paralleled a reelevation of the ST segment, secondary to a reccelusion of the Infarct-related veasel. Anglo = andogrephy, PTCA = percutaneous tranchuminal coronary andoplasty, TMI = Thrombolysis in Myocardlal Infarction; VM = vector magnitude. grade 0 or 1) the mean time-to-peak (TTP) from onset of symptoms was 20.1 hours. In patients who achieved reperfusion (TIMI 2 or 3 ) the mean TTP was 14.3 hours. In the nonreperfused group, the mean TTP from onset of pain was 16.1 hours and this did not differ significantly from the TTP of the reperfused group. Peaking of plasma CK within 4 hours after starting thrombolysis is highly suggestive of reperfusion. Late peaking, $>16$ hours after starting thrombolysis, rarely indicated reperfusion. A major drawback of this reperfusion index is the considerable overlap of the TTP ranges in the reperfused and occluded patient groups between 4 and 16 hours. Another limitation of TTP CK as a reperfusion index is the overestimation of druginduced reperfusion by including patients who had a subtotal occlusion at the time of treatment.

Garabedian et $\mathrm{al}^{34}$ documented that a $>2.5$-fold incrcase in CK-MB levels at the end of a 90-minute recombinant tissue-type plasminogen activator (rtPA) infusion provided evidence for reperfusion of the left anterior descending coronary artery (sensitivity of $93 \%$ and specificity of $83 \%$ ) and that a $>2.2$-fold increase in CK-MB levels could identify reperfusion of the right coronary artery (sensitivity of $89 \%$ and specificity of $100 \%$ ). Slightly different cutoff points were proposed because of the greater prevalence of well-developed collateral circulation in the right coronary artery circulation bed. Failure of this CK-MB increase ratio to detect reperfusion may result from initial presence of subtotal occlusion, well-developed collateral circulation, or cyclic reperfusion and reocclusion.

Creatine kinase isoforms: Zonal electrophoresis is widely used for separation of CK-MM, CK$\mathrm{MB}$, and CK-BB in the routine clinical chemistry laboratory. ${ }^{29}$ Prolonging the $\mathrm{CK}$ isoenzyme electrophoresis time, increasing the voltage, or using isoelectric focusing revealed at least 3 isoforms of CK-MM (denoted CK-MM $M_{1-3}$ or CK-3 ${ }_{1-3}$ ) and at least 2 isoforms of $\mathrm{CK}-\mathrm{MB}$ (denoted $\mathrm{CK}-\mathrm{MB}_{1-2}$ or $\left.\mathrm{CK}-2_{1-2}\right) .{ }^{35-40}$ The $\mathrm{CK}$ isoforms are no true isoenzymes but result from post-translational modification in serum of the CK-M subunil by a CK conversion factor, i.e., carboxypeptidase $\mathrm{N}^{41}$ In case of CK- $\mathrm{MM}_{3}$, the tissue isoform, hydrolytic cleavage of the carboxy-terminal lysine gives rise sequentially to CK-MM $\mathrm{MM}_{2}$ and $\mathrm{CK}-\mathrm{MM}_{1}$ (most anodal fraction). $\mathrm{CK}-\mathrm{MB}_{2}$ is converted to $\mathrm{CK}-\mathrm{MB}_{1}$. The discovery of probably 3 isoforms for CK-MB is recent and yet no commercialized methods exist that recognize these $3 \mathrm{CK}-\mathrm{MB}$ isoforms. ${ }^{42,43}$

The interpretation of electrophoresis data of serum CK following acute myocardial infarction has been complicated because of contradictions in 
nomenclature. The International Union of Pure and Applied Chemistry-International Union of Biochemistry (IUPAC-IUB) Commission on Nomenclature prescribes that the most anodal isoenzyme should be identified with the lowest arabic numerical, i.e., $\mathrm{CK}-\mathrm{BB}=\mathrm{CK}-1, \mathrm{CK}-\mathrm{MB}=\mathrm{CK}-2$, and CK-MM $=$ CK-3. In practice, letter subscripts have been replaced by numbers: CK-MB $=\mathrm{CK}-2$ and the anodal conversion is represented by $\mathrm{CK}-2{ }_{2} \rightarrow \mathrm{CK}-2_{1} \cdot{ }^{29,44}$

The reperfusion results after induced acute myocardial infarction in dogs suggested that prompt detection of reperfusion is possibly based on analysis of sequential changes in the plasma CK-MM isoform activities. ${ }^{45,46} \mathrm{CK}$ isoforms are not usually routinely determined in most clinical laboratories. ${ }^{25}$ So far, different technologies have been applied to separate and quantitate the CK isoforms. ${ }^{25,47}{ }^{57}$ Analytical performance of these methods is poorly documented, ${ }^{48}$ yet, electrophoresis is reported to be the most cost-effective, practical, reproducible, and sensitive method. However, differences in method specificity have also bccn reported, isoelectric focusing and high-voltage electrophoresis techniques being denaturating and producing artifacts (extra bands). ${ }^{48}$

Although several of these methods allow for 45-minute turn-around times, none is suitable for stat analysis because they are too laborious and specialized. Future potential for the clinical application of CK-MM and CK-MB isoforms depends on the development of simple, rapid, and automated systems. Recently, a sufficiently automated high-voltage electrophoresis analyzer (REP, Helena Laboratories, Beaumont, Texas $)^{58}$ that fulfills these requirements has been introduced. Also, monoclonal antibodies specific to certain CK isoforms became available. ${ }^{59-61}$ The future development of rapid, automated immunoassays that quantitate specific isoforms may provide the basis for a new generation of immunoassay tests that distinguish tissue isoforms from serum isoforms.

CK-MM ISOFORMS: Seacord et $\mathrm{al}^{62}$ found a marked increase of the percent CK-MM $\mathrm{MM}_{3}$ activity over the first hour postdosing in all patients with successful reperfusion. Apple et al ${ }^{40}$ found that the CK-MM $\mathrm{MM}_{3}$ CK-MM $\mathrm{M}_{1}$ ratio peaked significantly earlier than total CK and CK-MB in both reperfused and occluded individuals. Morelli et al ${ }^{63}$ confirmed these findings and documented that the TTP of the CK-MM $M_{3} / \mathrm{CK}-\mathrm{MM}_{1}$ ratio in the first 3 hours postdosing differentiated reperfused from nonreperfused individuals $(p<0.01)$. On the other hand, the serum appearance constant of CK- $\mathrm{MM}_{3}$ also differentiated successfully versus unsuccessfully reperfused patients with acute myocardial infarction. ${ }^{63,64}$ Puleo et $\mathrm{al}^{65}$ studied the rate of decline of plasma CK-MM $\mathrm{MM}_{3}$ levels over 18 hours after onset of infarction. They found a sensitivity of $87 \%$ and a specificity of $74 \%$ when a minimum rate of decline of $3.1 \% \mathrm{hr}^{-1}$ was exceeded.

The group of Abendschein et $\mathrm{al}^{66}$ reported that conjoint analysis of percent CK- $\mathrm{MM}_{3}$ and myoglobin increases over the first hour following initiation of thrombolysis, when these increases exceeded $0.18 \% \mathrm{~min}^{-1}$ and $2.6 \mathrm{ng} / \mathrm{mL} \mathrm{min}^{-1}$, respectively, provide robust noninvasive criteria for reperfusion evaluation.

In summary, (1) the determination of the rate of decrease of percent CK- $\mathrm{MM}_{3}$ is less suitable for reperfusion evaluation because of the requisite time delay (preventing additional interventions to salvage myocardium at a time when this can be initiated effectively), and because it is influenced by the residual stenosis grade and the amount of collateral blood flow. (2) Determination of the TTP of the percent CK-MM $\mathrm{MM}_{3}$ and the appearance constant $\left(K_{\mathrm{a}}\right)$ of CK-MM $\mathrm{MM}_{3}$ are impractical as reperfusion indices because of the requisite time delay and repeated blood sampling necessary to cstablish the peak or to calculate $K_{\mathrm{a}}$. (3) The rate of increase of the percent $\mathrm{CK}-\mathrm{MM}_{3}$ or $\mathrm{CK}-\mathrm{MM}_{3} / \mathrm{CK}-\mathrm{MM}_{1}$ ratio is superior for reperfusion evaluation. The rate of increase of percent $\mathrm{CK}-\mathrm{MM}_{3}$ is the earliest available reperfusion index because only $2-3$ plasma specimens, sampled before and within 1 hour after starting thrombolysis, are required.

CK-MB ISOFORMS: CK-MM and its isoforms lack cardiac specificity; in contrast, CK-MB isoforms are more cardiac specific. ${ }^{67,68}$ Until recently, available MB isoform assays lacked the necessary analytical sensitivity to detect CK-MB isoforms in normal plasma, ${ }^{47,48}$ yet sensitive assays with good analytical performance are available. ${ }^{49,69}$ Christenson et $\mathrm{al}^{68}$ found that the $\mathrm{CK}-\mathrm{MB}_{2} / \mathrm{CK}-\mathrm{MB}_{1}$ ratio peaked 90 minutes after starting thrombolysis, compared with the 2-hour time to peak for the $\mathrm{CK}-\mathrm{MM}_{3} / \mathrm{CK}-\mathrm{MM}_{1}$ ratio in the study of Morelli et al. ${ }^{63}$ Puleo et $\mathrm{al}^{70}$ concluded that the CK-MB $/ \mathrm{CK}$ $\mathrm{MB}_{1}$ ratio provided the best discrimination between reperfused and nonreperfused individuals within 1 hour after onset of pain. The limited body of clinical data on the utility of CK-MB isoform indices for reperfusion evaluation needs to be extended in order to understand their future potential. Especially, the existence of perhaps 3 CK-MB isoforms must be clarified. .2, $^{43}$

Myoglobin: Myoglobin is a cytosolic hemoprotein in cardiac and skeletal muscles $\left(M_{r} 17,700\right)$ necessary for the last step in the oxygen transport 
to the mitochondria. ${ }^{71,72}$ Normal serum levels of myoglobin are reported to be in the range of 6-85 $\mathrm{ng} / \mathrm{mL}$ and $4-60 \mathrm{ng} / \mathrm{mL}$ for men and women, respectively. ${ }^{30}$ After acute myocardial infarction, the serum concentration of myoglobin becomes abnormal in about 2 hours, peaks in about 6-9 hours, and becomes normal in 24-36 hours. Myoglobin increases up to 10 times the baseline level. Renal impairment, vigorous exercise, and many other conditions can influence the serum myoglobin levels. ${ }^{30}$ Myoglobinemia has also been described to be useful for evaluation of skeletal muscle damage. ${ }^{73,74}$ The advantage offered by myoglobin as a marker for myocardial injury is that it appears earlier in the peripheral blood circulation compared with $\mathrm{CK}, \mathrm{CK}-\mathrm{MB}$, and the $\mathrm{CK}$ isoforms. ${ }^{75-80}$.

Myoglobin kinetics after coronary artery ligation and subsequent reperfusion in dogs show a rapidly evolving time pattern, with peak concentrations at 45 minutes after vessel reopening. ${ }^{81}$ Despite its interesting kinetics, the myoglobin measurement has not been used extensively in the past. Reasons were the lack of reliable, rapid, and automated myoglobin assays, ${ }^{47}$ as well as the poor specificity of the protein (60-95\%), with large amounts being present in skeletal muscle. In the past a complement fixation test, numerous radioimmunoassays, and a semiquantitative latex test have been developed. Recently, however, stat immunoassays have been introduced on the European market. ${ }^{82,83}$ Behring Diagnostics (Behringwerke, Marburg, Germany) commercialized 2 myoglobin immunoassays: (1) an automated nephelometric fixed-time method with NA-latex myoglobin reagent on a $\mathrm{BN} 100$ or BNA nephelometer (Behring Diagnostica) that produces results within $20 \mathrm{~min}$ utes (12 minutes analysis time); and (2) a manual turbidimetric immunoassay on the precalibrated Behring Turbitimer with Turbiquant myoglobin reagent that produces results within 180 seconds. The latter reagent can also be applied on routine clinical chemistry analyzers that are capable of measuring optical turbidity at $340 \mathrm{~nm}$. Also, a 1-step 2-site particle concentration fluorescence immunoassay using monoclonal antibodies has been described. ${ }^{84}$

Kinetics of myoglobin appearance depend on infarct reperfusion and TIMI flow grade scores. Differences in kinetics between reperfused and nonreperfused arteries in patients with acute myocardial infarction will be reflected by different TTP values, different peak levels, and different rates of increase.
Ellis et $\mathrm{al}^{80}$ found a mean TTP of 111 minutes and 360 minutes in the reperfused and nonreperfused groups, respectively. They described a mean $T_{25-100}$ (i.e. the time required for myoglobin to increase from $25 \%$ to $100 \%$ of the peak level) of 71 and 341 minutes in the reperfused and nonreperfused groups, respectively. A $>4.6$-fold increase the first 2 hours following initiation of thrombolysis correctly identified $85 \%$ of the reperfused patients and $100 \%$ of the nonreperfused patients.

Katus and coworkers ${ }^{85}$ determined the predictive power of the TTP values of myoglobin, CK, and CK-MB in their recanalization study. In case of recanalization $<3.5$ hours after onset of chest pain, the probability of correct classification varied between $90-100 \%$. In case of late reperfusion, the probability of correct classification ranged between 5-99\%. Myoglobin allowed the earliest and best discrimination between reperfused and nonreperfused individuals. These findings fit with the data of McCullough et $a l,{ }^{86}$ who also concluded that TTP analysis of myoglobin is not useful as a reperfusion index because of the large overlap of TTP values for reperfused and nonreperfused patients.

Clemmensen et $a^{87}$ also evaluated TTP of myoglobin as a reperfusion index and concluded that peak myoglobin levels reached within 4 hours after starting thrombolysis accurately predict coronary reperfusion with $91 \%$ sensitivity and $88 \%$ specificity, and this within the time limit in which rescue angioplasty is still effective.

Ishii et $\mathrm{al}^{88}$ calculated a myoglobin and CK-MB ratio (defined as the ratio of the level at 15,30 , or 60 minutes after reperfusion to the level before reperfusion). The predictive accuracy of a myoglobin ratio $>2.4$ at 15 minutes was $96 \%$; for CK-MB the predictive accuracy of a CK-MB ratio $>2$ at 15 minutes was only $68 \%$. Consequently, the myoglobin ratio at 15 minutes was found to be a reliable marker of reperfusion and more useful than CK-MB for detection of reperfusion within 30 minutes.

Dillon et al ${ }^{89}$ calculated and estimated myoglobin appearance rates (estimated $K_{\mathrm{a}}=$ rate of myoglobin increase over the first hour to myoglobin at the time of application of therapy). A significantly higher mean $K_{\mathrm{a}}$ was found in the reperfused group $\left(0.122 \pm 0.182 \mathrm{~min}^{-1}\right.$ [mean $\left.\left.\pm \mathrm{SD}\right]\right)$ versus the nonreperfused group $\left(0.005 \pm 0.003 \mathrm{~min}^{-1}\right)$.

\section{CONCusion}

Continuous multilead ST monitoring techniques are of clinical use for prediction of vessel status early after myocardial infarction. In addi- 
tion, with the introduction of myoglobin as a biochemical parameter, a real-time relation with electrical events during acute myocardial infarction and subsequent reperfusion can be observed. Consequently, myoglobin seems to be the monitoring biochemical parameter of choice for the evaluation of coronary reperfusion within the time limits during which additional therapeutical interventions are feasible and effective.

Future studies are needed to prove if the combined evaluation of clinical, electrocardiographic, and enzymatic monitoring will provide the optimal information for assessing coronary patency after thrombolysis.

\section{REFERENGES}

1. Simoons ML, Vos J, Tijssen JGP, Vermeer F, Verheugt FWA, Krauss XH, Cats VM. Long term benefit of early thrombolytic therapy in patients with acute myocardial infarction: 5 year follow-up of a trial conducted by the Interuniversity Cardiology Institute of The Netherlands. I Am Coll Cardiol 1989;14:1609-1615.

2. Califf RM, O'Neill W, Stack RS, Aronson L, Mark DB, Mantell S, George BS, Candela RJ, Kereiakes DJ, Abbottsmith C, Topol EJ. Failure of simple clinical measurements to predict reperfusion status after intravenous thrombolysis. Ann Intem Med 1988;108:658-662.

3. Kircher BJ, Topol EJ, O'Neill WW, Pitt B. Prediction of infarct coronary artery recanalization after thrombolytic therapy. Am J Cardiol 1987;59:513-515. 4. Hohnloser SH, Zabel M, Kasper W, Meinertz T, Just H. Assessment of coronary artery patency after thrombolytic therapy: accurate prediction utilizing the combined analysis of three noninvasive markers. $J$ Am Coll Cardiol 1991;18: 44-49.

5. Shah PK, Cercek B, Lew AS, Ganz W. Angiographic validation of bedside markers of reperfusion. J Am Coll Cardiol 1993;21:55-61.

6. von Essen R, Merx W, Effert S. Spontaneous course of ST segment elevation in acute anterior myocardial infarction. Circulation 1979;59:105-112.

7. Rentrop P, Blanke H, Karsch KR, Kaiser H, Kostering H, Leitz K. Selective intracoronary thrombolysis in acute myocardial infarction and unstable angina pectoris. Circulation 1981;63:307-315.

8. Anderson JL, Marshall HW, Bray BE, Lutz JR, Frederick PR, Yanowitz FG, Datz FL, Klausner SC, Hagan AD. A randomized trial of intracoronary streptokinase in the treatment of acute myocardial infarction. $N$ Engl $J$ Med 1983;308:1312-1318.

9. Blanke H, Scherff F, Karsch KR, Levine RA, Smith H, Rentrop P. Electrocardiographic changes after streptokinase-induced recanalization in patients with acute left anterior descending artery obstruction. Circulation 1983;68:406412.

10. von Essen R, Schmidt W, Uebis R, Edelmann B, Effert S, Silny J, Rau G. Myocardial infarction and thrombolysis. Electrocardiographic short term and long term results using precordial mapping. Br Hean $J$ 1985;54:6-10.

11 Clemmensen $P$, Ohman M, Sevilla DC, Peck S, Wagner NB, Quigley PS, Grande P, Lee KL, Wagner GS. Changes in standard electrocardiographic ST-segment elevation predictive of successful reperfusion in acute myocardial infarction. Am J Cardiol 1990;66:1407-1411.

12. Saran KK, Been M, rurniss SS, Hawkins ' $I$, Reid DS. Reduction in SI segment elevation after thrombolysis predicts either coronary reperfusion or preservation of left ventricular function. Br Heart $J$ 1990;64:113-117.

13. Hogg KJ, Hornung RS, Howie CA, Hockings N, Dunn FG, Hillis WS. Electrocardiographic prediction of coronary artery patency after thrombolytic treatment in acute myocardial infarction: use of the ST segment as a noninvasive marker. Br Heart $J$ 1988;60:275-280.

14. Nicolau JC, Lorga AM, Garzon SAC, Jacob JLB, Machado NCS, Bellini AJ, Greco OTG, Marques LAF, Braile DM. Clinical and laboratory signs of reperfusion: are they reliable? Int J Cardiol 1989;25:313-320.

15. Barbash GI, Roth A, Hod H, Miller HI, Rath S, Har-Zahav Y, Modan M, Seligson U, Battler A. Kaplinski E, Rabinowitz B, Laniado S. Rapid resolution of ST elevation and prediction of clinical outcome in patients undergoing thrombolysis with alteplase (recombinant tissue-type plasminogen activator): results of the Israeli study of early intervention in myocardial infarction. $\mathrm{Br}$ Heart J 1990;64:241-247.
16. Richardson SG, Morton P, Murtagh JG, Scott ME, O'Keeffe DB. Relation of coronary arterial patency and left ventricular function to electrocardiographic changes after streptokinase treatment during acute myocardial infarction. Am J Cardiol 1988;61:961-965.

17. The TIMI Study Group: The Thrombolysis in Myocardial Infarction (TIMI) Trial. N Engl J Med 1985;312:932 936.

18. Kwon K, Freedman SB, Wilcox I, Allman K, Madden A, Carter GS, Harris PJ. The unstable ST segment early after thrombolysis for acute infarction and its usefulness as a marker of recurrent coronary occlusion. $A m J$ Cardiol 1991;67:109-115.

19. Krucoff MW, Croll MA, Poe JE, Pieper KS, Kanai PM, Granger CB, Veldkamp KF, Wagner BL, Sawchak SI, Califf RM. Continuously updated 12 lead ST-segment recovery analysis for myocardial infarct artery patency assessment and its correlation with multiple simultaneous early angiographic observations. Am J Cardiol 1993;71:145-151.

20. Krucoff MW, Green CE, Satler LF, Miller FC, Pallas RS, Kent KM, Del Negro A. Pearle DL. Fletcher RD, Rackley CE. Noninvasive detection of coronary artery patency using continuous ST-segment monitoring. Am J Cardiol 1986;57:916-922.

21. Krucoff MW, Wagner NB, Pope JE, Mortara DM, Jackson YR, Bottner RK, Wagner GS, Kent KM. The portable programmable microprocessordriven real-time 12-lead electrocardiographic monitor: a preliminary report of a new device for the noninvasive detection of successful reperfusion or silent reocclusion. Am J Cardiol 1990;65:143-148.

22. Dellborg $M$, Riha M, Swedberg K. Dynamic QRS-complex and STsegment monitoring in acute myocardial infarction during recombinant tissuetype plasminogen activator therapy. Am J Cardiol 1991;67:343-349.

23. Dellborg M, Topol EJ, Swedberg K. Dynamic QRS complex and ST segment vectorcardiographic monitoring can identify vessel patency in patients with acute myocardial infarction treated with reperfusion therapy. Am Heart $J$ 1991;122,4:943-948.

24. Dellborg $M$, van den Brand $M$, Dietz $R$, Sen S, Simoons ML, Stege G, Swedberg K, on behalf of the VERMUT-study. Dynamic electrocardiographic monitoring can determine early vessel patency after reperfusion therapy for acute myocardial infarction. (Abstr.) Eur Hear $J$ 1992;13(suppl):187.

25. Kwong TC, Fitzpatrick PG, Rothbard RL. Activities of some enzymes in serum after therapy with intracoronary streptokinase in acute myocardial infarc tion. Clin Chem 1984;30:731-734.

26. Panteghini M, Cuccia C, Calarco M, Gei P, Bozzetti E, Visioli O. Serum enzymes in acute myocardial infarction after intracoronary thrombolysis. Clin Biochem 1986;19:294-297.

27. De Zwaan Ch, Willems GM, Vermeer F, Res J, Verheugt FWA, van der Laarse A, Simoons ML, Lubsen J, Hermens WTh. Enzyme tests in the evaluation of thrombolysis in acute myocardial infarction. Br Heart $J$ 1988;60:175-183. 28. Wevers RA, Olthuis HP, Van Neill JCC, Van Wilgenburg MGM, Soons JBJ. A study on the dimeric structure of creatine kinase (E.C. 2.7.3.2.). Clin Chim Acta 1977;75:377-382.

29. Marshall T. Electrophoresis of serum isoenzymes and proteins following acute myocardial infarction. (Review.) J Chromatogr 1991;569:323-345.

30. Vaidya HC. Myoglobin. Lab Med 1992;23:306-310.

31. Lewis BS, Ganz W, Laramee P, Cercek B, Hod H, Shah PK, Lew A. Usefulness of a rapid initial increase in plasma creatine kinase activity as a marker of reperfusion during thrombolytic therapy for acute myocardial infarction. Am J Cardiol 1988;62:20-24.

32. Ong L, Reiser P, Coromilas J, Scherr L, Morrison J. Left ventricular function and rapid release of creatine kinase $\mathrm{MB}$ in acute myocardial infarction. Evidence for spontaneous reperfusion. N Engl J Med 1983;309:1-6.

33. Gore JM, Roberts R, Ball SP, Montero A, Goldberg RJ, Dalen JE. Peak creatine kinase as a measure of effectiveness of thrombolytic therapy in acute myocardial infarction. Am J Cardiol 1987;59:1234-1238.

34. Garabedian HD, Gold HK, Yasuda T, Johns JA, Finkelstein DM, Gaivin $\mathrm{RJ}$, Cobbaert $\mathrm{C}$, Leinbach $\mathrm{RC}$, Collen $\mathrm{D}$. Detection of coronary artery reperfusion with creatine kinase-MB determinations during thrombolytic therapy: correlation with acute angiography. J Am Coll Cardiol 1988;11:729-734.

35. Perryman MB, Strauss AW, Buettner TL, Roberts R. Molecular heterogeneity of creatine kinase isoenzymes. Biochim Biophys Acta 1983;747:284-290.

36. Chapelle JP, Heusghen C. Further heterogeneity demonstrated for serum CK isoenzyme MM. Clin Chem 1980;26:457-462.

37. Abendschein DR, Fontanet HL, Markam J, Sobel BE. Physiologic modeling of MM CK isoforms. Math Comput Modelling 1988;11:621-626.

38. Panteghini M. Serum isoforms of CK isoenzymes. Clin Biochem 1988;21:211215.

39. Abendschein DR, Morelli RL, Carlson CJ, Emilson B, Rapaport E. CK-MM isoenzyme subforms in myocardial, lymph, and blood after coronary artery occlusion. Cardiovasc Res 1984;18:690-693. 
40. Apple FS, Sharkey SW, Werdick M, Elsperger KJ, Tilbury RT. Analysis of CK isoenzymes and isoforms in serum to detect reperfusion after acute myocardial infarction. Clin Chem 1987;33:507-510.

41. Perryman MB, Knell JD, Roberts R. Carboxypeptidase-catalyzed hydrolysis of C-terminal lysine. Mechanism for in vivo production of multiple CK forms in plasma. Cin Chem 1985;30:662-665.

42. Billadello JJ, Fontanet HL, Strauss AW, Abendschein DR. Characterization of MB creatine kinase isoform conversion in vitro and in vivo in dogs. $J$ Clin Invest 1988;83:1637-1643.

43. Prager NA, Suzuki T, Jaffe AS, Sobel BE, Abendschein DR. Nature and time course of generation of isoforms of creatine kinase, MB fraction in vivo. $J$ Am Coll Cardiol 1992;20:414-419.

44. IUPAC-IUB Commission on Biochemical Nomenclature. Nomenclature of multiple forms of enzymes, recommendations (1976). Clin Chem 1977;23:41-44 45. Devries SR, Sobel BE, Abendschein DR. Early detection of myocardial reperfusion by assay of plasma MM-creatine kinase isoforms in dogs. Circulation 1986;74:567-572.

46. Nohara R, Myears DW, Sobel BE, Abendschein DR. Optimal criteria fo rapid detection of myocardial reperfusion by creatine kinase $\mathrm{MM}$ isoforms in the presence of residual high grade stenosis. J Am Coll Cardiol 1989;14:10671073 .

47. Apple FS. Acute myocardial infarction and coronary reperfusion. Serum markers for the 1990. Am J Clin Pathol 1992;97:217-226.

48. Wu AHB. Creatine kinase isoforms in ischemic heart disease. Clin Chem 1989;35:7-13.

49. Puleo PR, Guadagno PA, Roberts R. Sensitive, rapid assay of subforms of creatine kinase MB in plasma. Clin Chem 1989;35:1452-1455.

50. Shiesh SC, Ting WK, Jap TS. Measurement of creatine kinase isoforms by agarose gel clectrophoresis in the diagnosis of myocardial infarction. Clin Biochem 1992;25:293-301.

51. Vaidya HC, Maynard Y, Ditzler DN, Ladenson JH. Direct measurement of CK-MB in serum after extraction with monoclonal antibody specific to MB Clin Chem 1986;32:657-663.

52. Grace AM, Gualdoni J, Strauss AW, Sobel BE. Quantification of isoforms of plasma MM creatine kinase with an immunoblot procedure. Cathet Cardiovasc Diagn 1987;13:26-32.

53. Wu AHB, Gomet TG, Wu VH, Brockie RE, Nishikawa A. Early diagnosis of AMI by rapid analysis of CK-isoenzyme-3 subtypes. Clin Chem 1987;33:358 362.

54. Apple FS, Hellsten Y, Clarkson PM. Early detection of skeletal injury by assay of CK-MM isoforms in serum after acute exercise. Clin Chem 1988;34:11021105 .

56. Muller-Hansen S, Mathey DG, Bleifeld W, Voigt KD. Isoelectric focusing of creatine kinase MM isoforms and its application for diagnosis of acute myocardial infarction. Clin Biochem 1989;22:125-130.

86. Nohara R, Sobel B, Jaffe AS, Abendschein JR. Quantitative analysis for isoforms of creatine kinase MM in plasma by chromatofocusing, with on-line monitoring of enzyme activity. Clin Chem 1988;34:235-239.

57. Wu AHB, Gornet TG. Measurement of CK-MM sub-type by anion exchange liquid chromatography. Clin Chem 1985;31:1841-1844.

58. Escobar R, Gornet TG, Wu AHB. Evaluation of an automated electrophoresis analyzer for cardiac isocnzymes: the Helena Rep. (Abstr.) Clin Chem 1988;33:1284

59. Suzuki T, Shiraishi T, Tomita K, Totani M, Murachi T. Monoclona antibody inhibiting CK-MM3 but not isofonn CK-MM1. Clin Chem 1990;36:153156.

60. Panteghini M, Bonora R, Pagani F, Alebardi O. An immunochemical procedure for determination of creatine kinase31 (serum-specific) isoform in human serum evaluated. Clin Biochem 1990;23:225-228.

61 Christenson RH, Russell ME, Pizzo CK. Specificity of an antibody for precipitating the MB1 isoform of creatine kinase MB. (Abstr.). Clin Chem 1991;37:1023

82. Seacord LM, Abendschein DR, Nohara R, Hartzler G, Sobel E, Jaffe S. Detection of reperfusion within 1 hour after coronary recanalisation by analysis of isoforms of the MM creatine kinase isoenzyme in plasma. Fibrinobysis 1988;2: $151-156$.

63. Morelli RL, Emilson B, Rapaport E. MM-CK subtypes diagnose reperfusion early after myocardial infarction. Am J Med Sci 1987;293:139-149.

84. Panteghini $M$, Pagani $F$. Isoforms of creatine kinase isoenzymes in serum in acute myocardial infarction after intracoronary thrombolysis. Clin Chem 1987;33:2039-2042.
65. Puleo PR, Perryman MB, Bresser MA, Rokey R, Pratt CM, Roberts R. Creatine kinase isoform analysis in the detection and assessment of thrombolysis in man. Cinculation 1987;75:1162-1169.

66. Abendschein DR, Ellis A, Eisenberg PR, Klocke FJ, Sobel BE, Jaffe AS. Prompt detection of coronary recanalization by analysis of rates of change of concentrations of macromolecular markers in plasma. Coronany Anery Dis 1990 ; 2:201-212

67. Clarkson PM, Apple FS, Bymes WC, McCormick KM, Triffletti P. Creatine kinase isoforms following isometric exercise. Muscle Nenve 1987;10:41-45. 68. Christenson RH, Ohman EM, Clemmensen P, Grande P, Toffaletti J, Silverman LM, Vollmer RT, Wagner GS. Characteristics of creatine kinase-MB and $\mathrm{MB}$ isoforms in serum after repcrfusion in acute myocardial infarction. Clin Chem 1989;35:2179-2185.

69. Puleo PR, Guadagno PA, Roberts R, Scheel MV, Marian AJ, Churchill D, Perryman B. Early diagnosis of acute myocardial infarction based on assay for subforms of creatine kinase-MB. Circulation 1990;82:759-764.

70. Puleo PR, Perryman MB. Noninvasive detection of reperfusion in acute myocardial infarction based on plasma activity of creatine kinase MB subforms. J Am Coll Cardiol 1991;17:1047-1052

71 Wittenberg JB. Myoglobin-facilitated oxygen diffusion: role of myoglobin oxygen entry into muscle. Physiol Rev 1970;50:559-636.

72. Braunlin EA, Wahler GM, Swayze CR, Lucas RV, Fox IJ. Myoglobin facilitated oxygen diffusion maintains mechanical function of mammallian cardiac muscle. Cardiovasc Res 19;20:627-636.

73. Sabria-Leal M, Gimeno-Leal JM, Paret-Masana A, Rey-Jolo Barroso C. Myoglohin RIA in detecting carriers of Duchenne's muscular dystrophy. Eur Neurol 1986;25:253-255.

74. Leader $M$, Patel $J$, Collins $M$, Henry $K$. Myoglobin: an evaluation of its role as a marker of thabdomyosarcomas. Br J Cancer 1989;59:106-109.

75. McComb JM, McMaster EA, MacKenzie G, Adgey AAJ. Myoglobin and creatine kinase in acute myocardial infarction. Br Hear J 1984;51:189-194.

76. McComb JM, McMastcr EA, Adgcy AAJ. Myoglobin in the very early phase of acute myocardial infarction. Ann Clin Biochem 1985;22:152-155.

77. Roxin LE, Cullhed I, Groth T, Hallgren T, Venge P. The value of serum myoglobin determinations in the early diagnoxis of acute myocardial infarction. Acta Med Scand 1984;215:417-425.

78. Isakov A, Shapira I, Burke M, Almog C. Serum myoglobin levels in patients with ischemic myocardial insult. Arch Intem Med 1988;148:1762-1765. 79. Gibler WB, Gibler CD, Weinshenker E, Abbottsmith C, Hedges JR, Barsan WG, Sperling M, Chen I-W, Embry S, Kereiakes D. Myoglobin as an early indicator of acute myocardial infarction. Ann Emerg Med 1987;16;851-856. 80. Ellis AK, Little T, Zaki Masud AR, Liberman HA, Morris DC, Klocke FJ. Early non-invasive detection of suocessful reperfusion in patients with acute myocardial infarction. Circulation 1988;78:1352-1357.

81. Ellis AK, Little T, Zaki Masud AR, KJocke FJ. Patterns of myoglobin release after reperfusion of injured myocardium. Circulation 1985;72:639-647.

82. Delanghe JR, Chapelle JP, Vanderschueren SC. Quantitative nephelometric assay for determining myoglobin evaluated. Clin Chem 1990;36:1675-1678.

83. Delanghe J,R, Chapelle JP, el Allaf $M$, De Buyzere $M$. Quantitative turbidimetric assay for determining myoglobin evaluated. Ann Clin Biochem $1991 ; 28: 474-479$

84. Silva DP, Landt Y, Porter SE, Ladenson JH. Development and application of monoclonal antibodies to human cardiac myoglobin in a rapid fluorescence immunoassay. Clin Chem 1991;37:1356-1364.

85. Katus HA, Diederich KW, Scheffold T, Uellner M, Scharz F, Kubler W. Non-invasive assessment of infarct reperfusion: the predictive power of the time to peak value of myoglobin, CKMB and CK in serum. Eur Heart $J$ 1988;9:619-624.

86. McCullough DA, Harrison PG, Forshall JM, Irving JB, Hillman RJ. Serum myoglobin and creatine kinase enzymes in acute myocardial infarction treated with Anistreplase, $J$ Clin Pathol 1992;45:405-4107.

87. Clemmensen P, Jurlander B, Grande P, Ohman EM, Wagner GS. Monitoring peak serum-myoglobin for non-invasive prediction of coronary reperfusion in patients. Circulation 1991;84(suppl II):116.

88. Ishii $J$, Nomura $M$, Ando $T$, Hasegawa $H$, Kimura $M$, Tateishi $R$, Kurokawa $\mathrm{H}$, Kondo $\mathrm{T}$, Hishida $\mathrm{H}$, Mizuno $\mathrm{Y}$. Early detection of coronary reperfusion based on serum myoglobin concentration. Cinculation 1991;84(suppl II): 117.

89. Dillon GA, Ellis AK, Klocke FJ. Rapid determination of coronary reperfusion in acute MI patients using myoglobin kinetics. Circulation 1991;84(suppl II): 115 . 